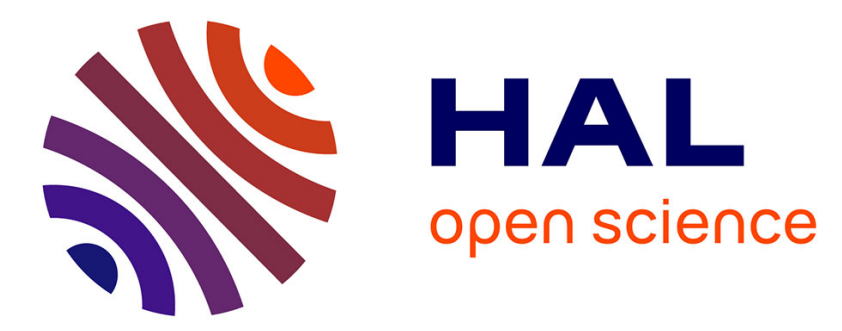

\title{
A new species of the genus Hilethera Uvarov, 1923 (Orthoptera: Acrididae: Oedipodinae) from China and its complete mitochondrial genome
}

Jiajia Dong, Zhenning Chen, Qingqing Wang, Delong Guan, Shengquan Xu, Tony Robillard

\section{To cite this version:}

Jiajia Dong, Zhenning Chen, Qingqing Wang, Delong Guan, Shengquan Xu, et al.. A new species of the genus Hilethera Uvarov, 1923 (Orthoptera: Acrididae: Oedipodinae) from China and its complete mitochondrial genome. Zootaxa, 2019, 4564 (2), pp.514. 10.11646/zootaxa.4564.2.10 . hal-02454368

\section{HAL Id: hal-02454368 https://hal.science/hal-02454368}

Submitted on 24 Jan 2020

HAL is a multi-disciplinary open access archive for the deposit and dissemination of scientific research documents, whether they are published or not. The documents may come from teaching and research institutions in France or abroad, or from public or private research centers.
L'archive ouverte pluridisciplinaire HAL, est destinée au dépôt et à la diffusion de documents scientifiques de niveau recherche, publiés ou non, émanant des établissements d'enseignement et de recherche français ou étrangers, des laboratoires publics ou privés. 


\title{
A new species of the genus Hilethera (Orthoptera: Acrididae: Oedipodinae) from China and its complete mitochondrial genome
}

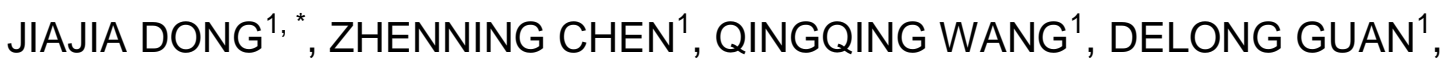 \\ SHENGQUAN XU1, *, TONY ROBILLARD ${ }^{2}$
}

${ }^{1}$ College of Life Sciences, Shaanxi Normal University, 710062, Xi'an, P.R. China. E-mail: jia_jia_dong@hotmail.com; xushengquan@snnu.edu.cn.

2 Institut de Systématique, Evolution et Biodiversité (ISYEB), Muséum national d'Histoire naturelle, CNRS, Sorbonne Université, EPHE, 57 rue Cuvier, CP 50, 75231 Paris Cedex 05, France.

\section{Abstract}

The new species, Hilethera xinjiangensis sp. nov. (Orthoptera: Acrididae: Oedipodinae) is described based on specimens collected from Xinjiang, northern China. The new species is similar to $H$. brevipennis Zheng \& Lu, 2002 and $H$. turanica Uvarov, 1925, but differs from: (1) dark brown in general coloration, (2) darker coloration in forewings, (3) forewings longer than $H$. brevipennis but shorter than $H$. turanica, (4) cubital area of forewings boarder than $H$. brevipennis and $H$. turanica, (5) hind tibiae dark brown with two light yellow pre-basal rings, while dark with one fade pre-basal ring in $H$. brevipennis and light yellow with three dark rings in H. turanica.

In addition, the complete mitogenome of holotype was sequenced using nextgeneration sequencing technology. The total length of the assembled mitogenome is 16,145 bp, representing 13 protein-coding genes, 22 transfer RNA genes, two ribosomal RNA genes and one noncoding region (D-loop region). Besides, the new mitogenome sequence is compared with published Oedipodinae mitogenomes and the phylogenetic relationships within the subfamily are reconstructed. The results infer that the gene cox1 could be a useful marker for higher phylogenetic level, while the genes $n d 5$ and $r r n L$ could be a potentially useful markers between closely related species.

Key words: new species, mitogenome, phylogenetic marker, China, Asia 


\section{Introduction}

The subfamily Oedipodinae is one of the few nearly globally distributed subfamilies within the short-horned grasshoppers (Caelifera), with major radiations in the Palaearctic as well as in the Nearctic, occupying every conceivable terrestrial habitats outside of the polar regions and playing important roles in the ecosystem (Uvarov, 1966; Vickery, 1977; Vickery, 1997; Vickery \& Kevan, 1983; Cigliano et al., 2018). Its diversity in numerous lineages, form and function has attracted attention in many biological fields, including systematics, evolutionary ecology and biogeography (e.g., Chapco \& Contreras, 2011; Husemann et al. 2012; Song et al., 2015, 2018).

According to the early study, the subfamily Oedipodinae had an ancient origin, before the separation of Laurasia from Africa (Vickery, 1989) and Asiamerica was the center of initial oedipodine radiation about 94 Mya (million years ago) (Fires et al., 2007). Based on recent available worldwide biogeographical framework of Orthopteran insects (Song et al., 2015, 2018), oedipodine grasshoppers, known as strong fliers and colonizers, may diverge from Africa ancestor in the late Paleocene, and undergo an explosive adaptive radiation, powered by the evolution of a new niche space (grasslands) and frequent founder events after the colonization of new habitats.

Within Oedipodinae, the genus Hilethera Uvarov, 1923 is characterized by long band wings and stubby legs. It is distributed widely, from Africa to Asia and containing habitat from Asia-temperate to tropical Africa (Cigliano et al., 2018). This wide distribution and high diversity in habitat suggest that Hilethera may constitute a valuable model to address questions about patterns of endemism, species diversification, evolution and biogeography.

To better understand the origin and evolution of the genus Hilethera, basic data are needed for as many species as possible, and this in turn necessitates taxonomic and biological studies, e.g., molecular markers for species identification (Hajibabaei et al., 2007; Crampton-Platt et al., 2016). Since the genus was established by B. P. Uvarov in 1923, 11 species were recorded on the Orthoptera Species File (OSF, Cigliano et al., 2018). However, there is not yet molecular work related to Hilethera species.

In this study, we report a new species and present its complete mitogenome. Furthermore, comparative and phylogenetic analyses within Oedipodinae 
mitogenomes are given to help understand the evolution characterization of mitogenome structure of Oedipodinae and provide a preliminary phylogeny of Oedipodinae for future research.

\section{Materials and Methods}

Materials. The new material was collected in the expedition of Xinjiang, China, and deposited in the museum of Shaanxi Normal University.

Molecular techniques. Total genomic DNA was extracted from the hind femur muscles using the traditional cetyltrimethylammonium bromide (CTAB) method. Total genomic DNA was sequenced using the Illumine $\mathrm{HiSeq}^{\mathrm{TM}_{2}} 250$ platform (Biomarker technologies Co., Ltd., Beijing, China). In all, 7.48 million raw reads of $250 \mathrm{bp}$ each were retrieved. They were quality-trimmed with Trimmomatic v0.35 (Bolger et al., 2014), and then were used to assemble the mitochondrial genome using a MIRA4/Mitobim combined pipeline (Hahn et al., 2013) with a complete mitochondrial genome of Aiolopus thalassinus (GenBank accession Number: NC_034674) as the initial reference. The molecular service including total genomic DNA extraction and sequencing were completed at the Biomarker technologies company in China. The mitogenome assembly was carried out on the computer workstation of Shaanxi University, China.

Sequence analysis. Annotation of the mitogenome was performed using the MITO webserver with invertebrate genetic code (Bernt et al., 2013) and modified after comparisons with other mitogenomes from Oedipodine species. The validation of tRNA sequences was performed in tRNAscan-SE using the invertebrate mitogenome genetic codon (http://lowelab.ucsc.edu/tRNAscan-SE/; Lowe \& Chan, 2016). The nucleotide base composition of the complete mitogenome was calculated in GENEIOUS R9 (Biomatters Ltd., Auckland, New Zealand). The nucleotide compositional skew was calculated following the formula (Konstantionv et al., 2016): $A T$-skew $=(A-T) /(A+T)$ and $G C$-skew $=(G-C) /(G+C)$, where $A, C, G$ and $T$ are the frequencies of the four bases.

Besides the mitochondrial genomes of Hilethera xinjiangensis sp. nov., the nucleotide base composition comparison analysis for additional 15 Oedipodinae grasshopper mitogenomes from GenBank (see in Table 3) were also calculated, at 
the level of the whole mitogenomes, for the two ribosomal genes (the large and small ribosomal subunit, $r r n L$ and $r r n S$ ) and at the level of the A+T-rich region.

Pairwise genetic distances within 16 Oedipodine species based on single protein coding genes (PCGs) and two ribosomal genes ( $r r n L$ and $r r n S$ ) were calculated in GENEIOUS R9 (Biomatters Ltd., Auckland, New Zealand). Besides, the comparison analysis of synonymous and non-synonymous substitutions (Ka/Ks) for all PCGs in Oedipodinae were calculated using MEGA 7.0 (Kumar et al., 2016).

Phylogenetic analyses. In addition to the newly generated mitogenome of Hilethera xinjiangensis sp. nov., we used all available mitogenomes of Oedipodinae in GenBank to reconstruct the phylogeny of the subfamily. According to the previous studies (Chapco \& Contreras, 2011; Song et al., 2018), the subfamily Oedipodinae are not monophyletic, and was nested in the subfamilies Acridinae and Gomphocerinae. Therefore, we also add all available mitogenomes of the two latter families recorded in GenBank. The mitogenome of Ommexecha virens (accession number: NC_020778) and Tristira magellanica (accession number: NC_020773) were selected as outgroup. The dataset contained all three codon positions of 13 PCGs and two rRNAs ( $r r n L$ and $r r n S$ ). The final alignment implemented by GENEIOUS R9 (Biomatters Ltd., Auckland, New Zealand), and the concatenated dataset resulted in 13,451 bp sites. The concatenated dataset was then analyzed using Bayesian inference $(\mathrm{BI})$ and maximum likelihood (ML). For both $\mathrm{BI}$ and $\mathrm{ML}$ we used PartitionFinder V2.1.1 (Lanfear et al., 2017) to determine best-fit partitioning schemes and the associated substitution models. Bayesian inference analyses were performed with MrBayes 3.2.6 (Ronquist et al., 2012) whereas ML analyses were performed with IQ-TREE 1.6.2 (Nguyen et al., 2015). All corresponding analyses were performed using the CIPRES Science Gateway 3.3 (Miller et al., 2015).

\section{Abbreviations}

Measurements --- PronL: pronotum length; PronW: pronotum width; FWL: forewing length; FWW: forewing width; FIIIL: length of hind femora; FIIIW: width of hind femora; Is: inner spines on TIII dorsal side; Os: outer spines on TIII dorsal side; TIIIL: length of hind tibiae. 


\section{Taxonomic part}

\section{Subfamily Oedipodinae Walker, 1871}

\section{Tribe Epacromiini Brunner von Wattenwyl, 1893}

\section{Genus Hilethera Uvarov, 1923}

Lerina Bolivar, 1902: 602 (nom. Praeocc.).

Lerinnia Uvarov, 1940: 176 (Syn. nov.);

Hilethera Uvarov, 1923: 82; 1925: 33; B.-Bienko \& Mistshenko, 1951: 570; Dirsh, 1958: 56; Dirsh, 1965: 398; Zheng, 1993: 442; Yin et al., 1996: 332; Zheng \& Xia, 1998: 616; Zheng \& Lu, 2002: 16; Bughio et al., 2012.

Type species: Hilethera hierichonica Uvarov, 1923

Diagnosis. Size medium to small among the subfamily Oedipodinae with compressed black spots. Head shorter than pronotum. Vertex wide and short. Face slightly sloping backward. Fastigium of vertex protruded and flat, lacking median keel. Eyes large and oval shaped. Foveolae distinctly triangular. Antennae slender, filiform. Median keel of pronotum depressed and thin, cut only by posterior transverse sulcus located above the middle of pronotum, while lateral keel weak or nearly absent in the metazona; posterior margin of pronotum right-angled or obtusely angulate. Interspace of mesosternal lobes wide. Tegmina and hind wings well developed, surpassing apex of hind femora. Median intercalary vein of forewings approaching to median vein or between median vein and cubitus, without cross veins before median intercalary vein; cubital area wider than medial area, with or without intercalary vein. Median vein and precubitus of hing wings close, without dark transverse stripe. Hind femora short and thick, mostly dark in the inner side. Hind tibiae distinctly shorter than hid formora. Aroliums between claws of tarsus small. Subgenital plate of male short conical.

Distribution. Central and western Asia, Africa. 


\section{Hilethera xinjiangensis sp. nov.}

(Figs 1-2)

Material examined. Holotype (male): China, Xinjiang, Burqin Kanas, $48.2244^{\circ} \mathrm{N}$, 87.0053 $\mathrm{E}, 1172 \mathrm{~m}, 23$ June 2017, coll. Zhenning Chen \& Haisheng Chen. Paratypes. China, same locality as holotype, Xinjiang, Burqin Kanas, $48.2244^{\circ} \mathrm{N}$, 87.0053 $\mathrm{E}, 1172 \mathrm{~m}, 23$ June 2017, 2 males, coll. Zhenning Chen \& Haisheng Chen.

Etymology. The species is named after the type locality.

Distribution. North of Xinjiang, China.

Diagnosis. Species of small size for the genus, close to $H$. turanica from Xinjiang, China and $H$. brevipennis from Shanxi, China, from which it differs by general coloration darker, length of tegmina shorter, coloration-banded in forewings and hind tibiae, and cubital area of forewings boarder. The major differences are listed in Table1.

Description. Male (holotype). Body small, stubby and short. Head slightly higher than pronotum in lateral view but shorter in dorsal view. Apex of vertex slightly protruding before eyes, anterior margin straight, weakly depressed in middle area; median keel of vertex slender, lateral margin prominent and distinctly higher than upper margin of eyes; vertex and frons forming roundness in profile. Foveolae elongate-triangular, with sharp, raised margins, the lower margin slightly incurved; foveola and vertex forming obtuse angle in dorsal view. Antennae filiform but incrassate, not extending to posterior margin of pronotum. Eyes large and prominent, oval, their longitudinal diameter about 1.4 times their horizontal diameter and about 1.5 times length of subocular furrow; median ocellus located between lower margins of eyes. Frontal ridge flat with a faint constriction near the ocellum; lateral margins of frontal ridge protruding and nearly parallel, the width of frontal ridge between the antennae slightly smaller than below median ocellus. In dorsal view, anterior margin of pronotum slightly round, posterior margin curved, forming nearly a right angle; median keel obvious, lateral keel absent in prozona while clearly present but irregularly curved in metazona; the length of prozona smaller than that of metazoan; anterior and media transverse sulci indistinct whereas posterior transverse sulcus distinct and cut by median keel. Lateral lobe of pronotum saddle-shaped with a distinct incision on posterior transverse sulcus, anterior and posterior margins of lateral lobe nearly parallel, lower margin S-shaped, anterior lower angle obtuse but 
posterior lower angle right-angle, lateral lobe of pronotum with two longitudinal and one short transverse sulci in prozona, and two long transverse sulci in metazona. Tegmina large, exceeding apex of femora but not reaching median of hind tibiae; length of tegmina about 6 times wider than wide. Cubital area of forewings about 1.7 times wider than medial area. Medial area with one distinct intercalary vein. Hind femur robust, about 3.7 times longer than wide, tip of lower knee lobe rounded. Posterior tibia with 11 spines on inner side and 11-12 spines on outer side, outer apical spine present. Arolium shorter than claw. Tympanal organ developed, tympanic cavity oval. Epiproct triangular, with broad median longitudinal sulcus, apex acute. Cercus conical, surpassing apex of epiproct. Subgenital plate long and conical, apex acute, surpassing apex of epiproct in dorsal view. Epiphallus with arch bridge, ancorae curved inward, apex pointed, lophi curved.

Coloration. Body dark brown. Eyes brown. Antennae yellowish brown with dark brown base. Pronotum dark brown with yellowish V-shape. Forewings dark brown with melanin spots on basal and anterior margin, and two fading stripes on median part; hind wings dark brown on anterior part and transparent on remaining part. Hind femora black dark with a preapical yellowish ring; knee lobes light yellow. Hind tibia dark brown with yellowish base and two light yellow pre-basal rings.

Female unknown.

Measurements. See Table 2.

TABLE 1. Comparison of Hilethera xinjiangensis sp. nov. with $H$. brevipennis and $H$. turanica.

\begin{tabular}{|c|c|c|c|}
\hline Characters & Hilethera xinjiangensis sp. nov. & H. brevipennis & H. turanica \\
\hline General coloration & dark brown & brown & brown \\
\hline Apex of forewing & $\begin{array}{l}\text { exceeding apex of femur but } \\
\text { not reaching the middle of hind } \\
\text { tibiae }\end{array}$ & $\begin{array}{l}\text { reaching to the apex of } \\
\text { hind femur }\end{array}$ & $\begin{array}{l}\text { reaching to the middle of } \\
\text { hind tibiae }\end{array}$ \\
\hline Coloration of forewing & $\begin{array}{l}\text { dark brown with two fading } \\
\text { stripes on median part }\end{array}$ & $\begin{array}{l}\text { two indistinct black } \\
\text { stripes on median part }\end{array}$ & $\begin{array}{l}\text { two black stripes on } \\
\text { median part }\end{array}$ \\
\hline Cubital area of forewing & $\begin{array}{l}1.7 \text { times wider than medial } \\
\text { area }\end{array}$ & $\begin{array}{l}1.5 \text { times wider than } \\
\text { medial area }\end{array}$ & $\begin{array}{l}1.3 \text { times wider than } \\
\text { medial area }\end{array}$ \\
\hline Hind tibiae & $\begin{array}{l}\text { dark brown with two light } \\
\text { yellow pre-basal rings }\end{array}$ & $\begin{array}{l}\text { dark with one fade } \\
\text { pre-basal ring }\end{array}$ & $\begin{array}{l}\text { light yellow with three } \\
\text { dark rings }\end{array}$ \\
\hline
\end{tabular}

TABLE 2. Measure of Hilethera xinjiangensis sp. nov. (in $\mathrm{mm}$, mean values in brackets).

\begin{tabular}{cccccccccc}
\hline & PronL & PronW & FWL & FWW & FIIIL & FIIIW & TIIIL & \multicolumn{2}{c}{ TIIIs } \\
\hline Holotype & & & & & & & & Is & Os \\
\hline Male paratype $(\mathrm{n}=2)$ & $(3.6)$ & $(2.7)$ & $(17.1)$ & $(2.8)$ & 4.7 & 2.2 & 10.1 & 11 & 12 \\
\hline Male $(\mathrm{n}=3)$ & $(3.6)$ & $(2.8)$ & $(17.0)$ & $(2.8)$ & $(4.8)$ & $(2.3)$ & $(10.5)$ & $(11)$ & $(11)$ \\
\hline
\end{tabular}



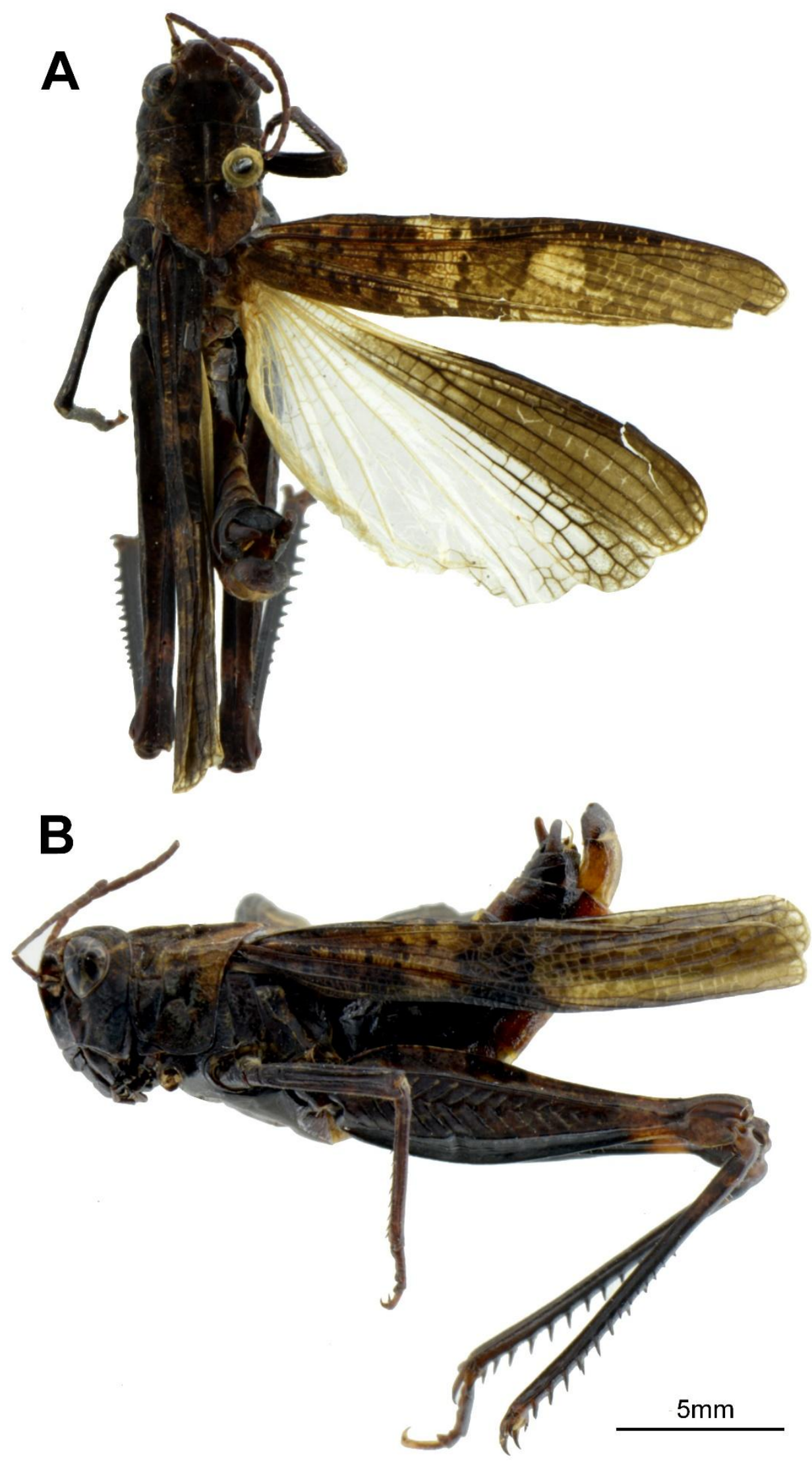

FIGURE 1. Hilethera xinjiangensis sp. nov. male habitus: dorsal (A) and lateral (B) views. Scale bar: $5 \mathrm{~mm}$. 


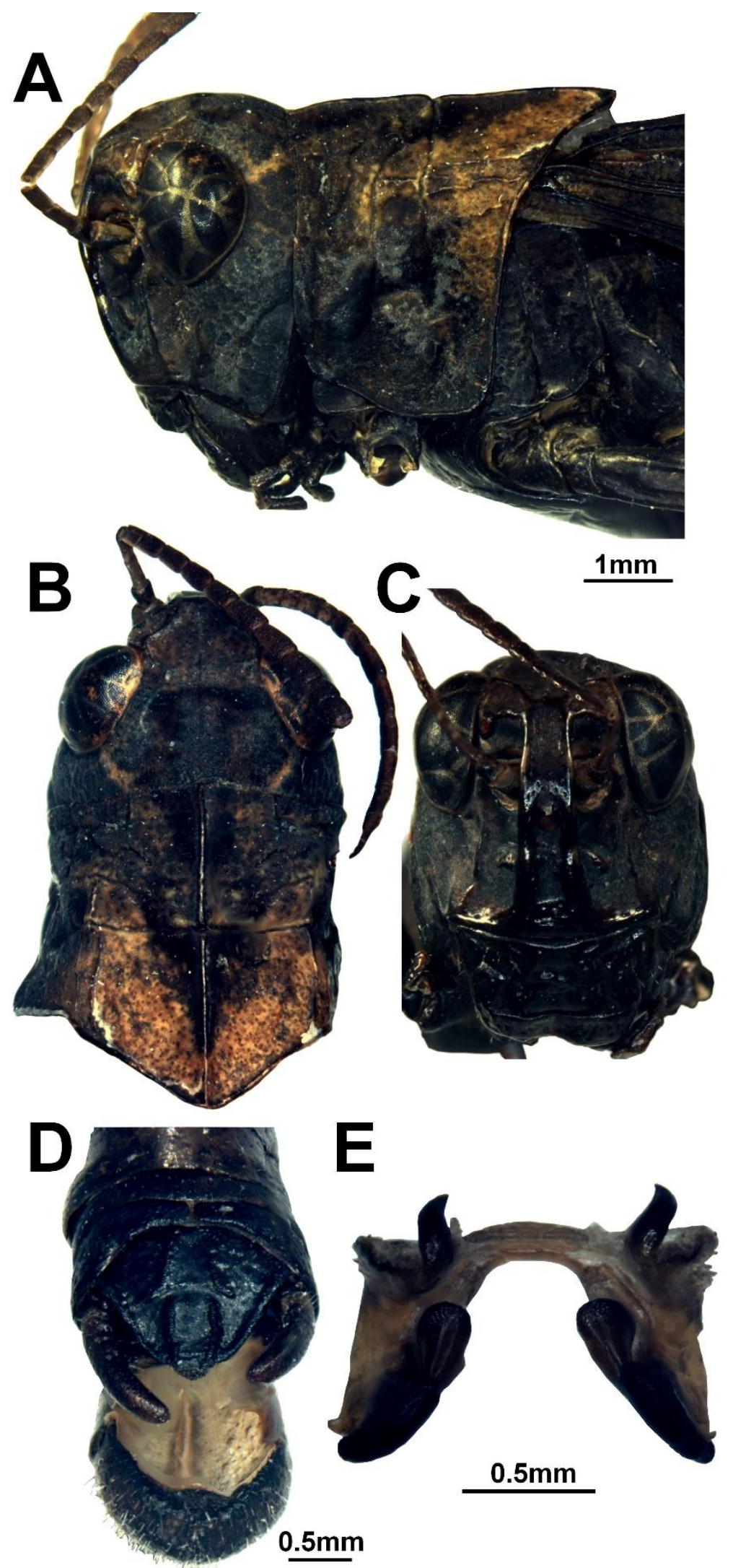

FIGURE 2. Hilethera xinjiangensis sp. nov. male: head and pronotum in lateral $(A)$ and dorsal (B) views; head in facial view (C); abdomen in dorsal view (D); epiphallus (E). Scale bar: $1 \mathrm{~mm}(\mathrm{~A}, \mathrm{~B}$ and $\mathrm{C}), 0.5 \mathrm{~mm}$ ( $\mathrm{D}$ and $\mathrm{E})$. 


\section{Molecular Results}

Genome organization, structure, and composition. The mitogenome of Hilethera xinjiangensis sp. nov. is 16,145 bp long (Fig. 3), organized in the typical set of 37 genes (13 protein-coding genes, 22 transfer RNA genes and two ribosomal RNA genes) and one $A+T$-rich control region (Table 3 ). There are $137 \mathrm{bp}$ intergenic nucleotides in total, in 17 locations, and the length of the intergenic spacers ranges in size from 1 to $30 \mathrm{bp}$. The longest intergenic spacer (30 bp) was located between the tRNA-Leu ${ }^{(\mathrm{UAG})}$ and tRNA-Val genes. Nine pairs of genes overlapped each other, with a length ranging from 1 to $8 \mathrm{bp}$, and with the longest overlap (8 bp) located between $n d 2$ and tRNA-Cys, and tRNA-Cys and cox1, respectively. Twelve pairs of genes are directly adjacent.

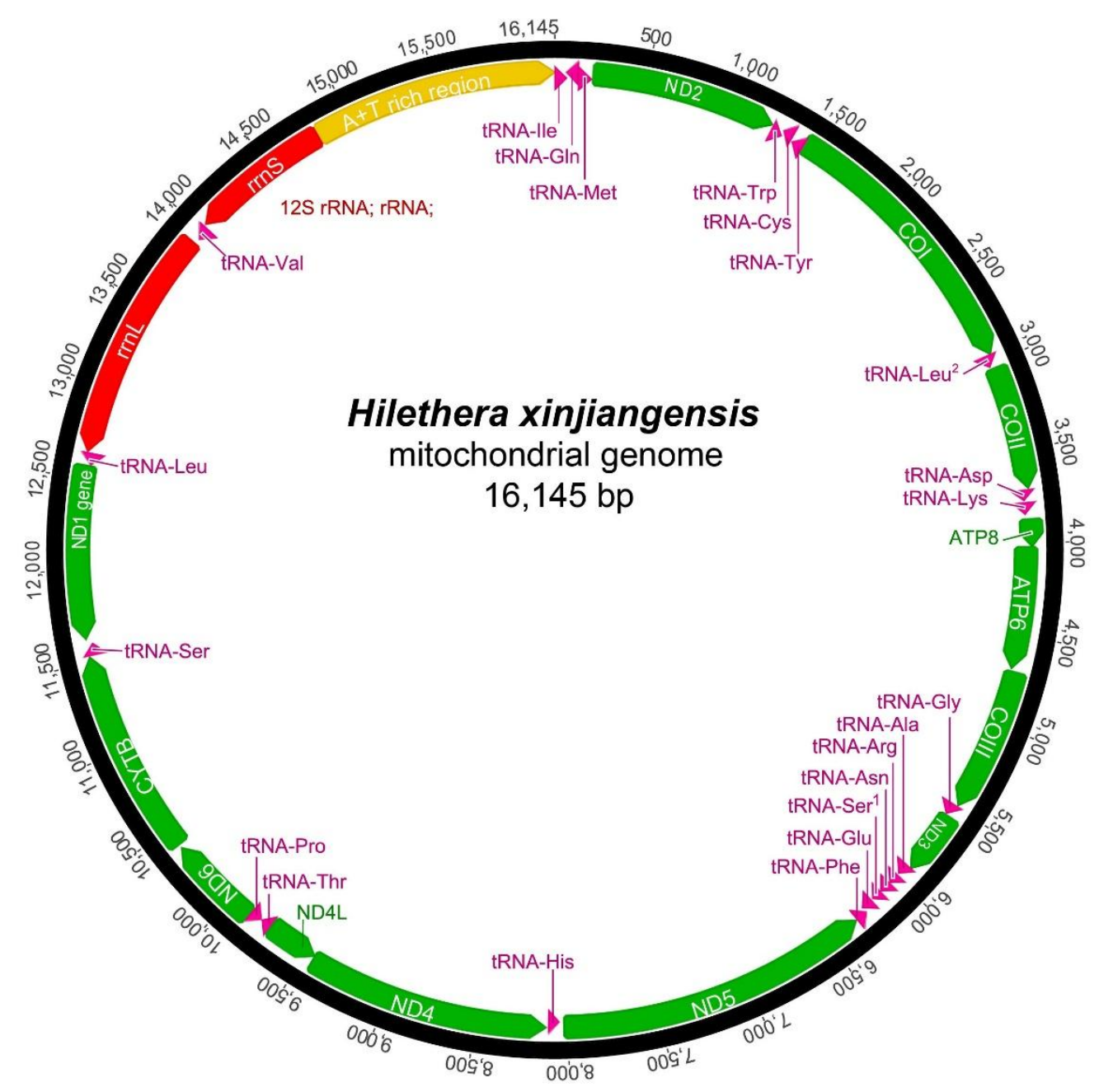

FIGURE 3. Map of the mitochondrial genome of Hilethera sp. nov. 
TABLE 3. Annotation of the mitochondrial genome of Hilethera xinjiangensis sp. nov.

\begin{tabular}{|c|c|c|c|c|c|c|}
\hline Gene & Strand & Anticodon & Start codon & Stop codon & Position & Length \\
\hline tRNA-Ile & + & $A \cup C$ & & & $1-67(-3)$ & 67 \\
\hline tRNA-GIn & - & UUG & & & $65-133(-1)$ & 69 \\
\hline tRNA-Met & + & AUG & & & $133-203(0)$ & 71 \\
\hline$n d 2$ & + & & ATG & $\mathrm{T}$ & 204-1,224 (0) & 1,021 \\
\hline tRNA-Trp & + & UCA & & & $1,225-1,290(-8)$ & 66 \\
\hline tRNA-Cys & - & GCA & & & $1,283-1,348(8)$ & 66 \\
\hline tRNA-Tyr & - & GUA & & & $1,357-1,423(-8)$ & 67 \\
\hline $\operatorname{cox} 1$ & + & & ATC & TAA & $1,416-2,955(0)$ & 1,540 \\
\hline tRNA-Leu ${ }^{2}$ & + & UUA & & & $2,956-3,021(7)$ & 66 \\
\hline $\cos 2$ & + & & ATG & $\mathrm{T}$ & $3,029-3,710(0)$ & 682 \\
\hline tRNA-Asp & + & GAC & & & $3,711-3,775(3)$ & 65 \\
\hline tRNA-Lys & + & AAG & & & $3,779-3,848(17)$ & 70 \\
\hline atp8 & + & & ATC & TAA & $3,866-4,024(-7)$ & 159 \\
\hline atp6 & + & & ATG & TAA & $4,018-4,695(4)$ & 678 \\
\hline $\cos 3$ & + & & ATG & TAA & $4,700-5,491(3)$ & 792 \\
\hline tRNA-Gly & + & GGA & & & $5,495-5,560(0)$ & 66 \\
\hline$n d 3$ & + & & ATT & TAG & $5,561-5,914(-2)$ & 354 \\
\hline tRNA-Ala & + & GCA & & & $5,913-5,977(5)$ & 65 \\
\hline tRNA-Arg & + & CGA & & & $5,983-6,047(0)$ & 65 \\
\hline tRNA-Asn & + & UUC & & & $6,048-6,113(0)$ & 66 \\
\hline tRNA-Ser ${ }^{1}$ & + & UGC & & & $6,114-6,180(3)$ & 67 \\
\hline tRNA-Glu & + & GUU & & & $6,184-6,249(-2)$ & 66 \\
\hline tRNA-Phe & - & GAA & & & $6,248-6,311(0)$ & 64 \\
\hline$n d 5$ & - & & ATT & $\mathrm{T}$ & $6,312-8,031(15)$ & 1,720 \\
\hline tRNA-His & - & GUG & & & $8,047-8,112(2)$ & 66 \\
\hline$n d 4$ & - & & ATG & TAA & $8,115-9,449(-7)$ & 1,335 \\
\hline$n d 4 I$ & - & & ATG & TAA & $9,443-9,736(2)$ & 294 \\
\hline tRNA-Thr & + & $A C A$ & & & $9,739-9,801(0)$ & 63 \\
\hline tRNA-Pro & - & UGG & & & $9,802-9,864(2)$ & 63 \\
\hline$n d 6$ & + & & ATG & TAA & $9,867-10,388(8)$ & 522 \\
\hline cytb & + & & ATG & TAA & $10,397-11,536(-1)$ & 1,140 \\
\hline tRNA-Ser ${ }^{2}$ & + & UCA & & & $11,536-11,605(20)$ & 70 \\
\hline$n d 1$ & - & & ATA & TAG & $11,626-12,570(3)$ & 945 \\
\hline tRNA-Leu ${ }^{1}$ & - & UAG & & & $12,574-12,638(0)$ & 65 \\
\hline$r r n L$ & - & & & & $12,639-13,925(30)$ & 1,287 \\
\hline tRNA-Val & - & UAC & & & $13,956-14,026(5)$ & 71 \\
\hline$r r n S$ & - & & & & $14,032-14,813(0)$ & 782 \\
\hline$A+T$-rich region & + & $N / A$ & & & $14,814-16,145(0)$ & 1,332 \\
\hline
\end{tabular}

Note: The number of intergenic nucleotides is shown in parentheses. The positive numbers indicate intergenic spacers between genes, the negative numbers indicate overlaps between genes, and the zero value means two genes are adjacent.

The nucleotide composition of $H$. xinjiangensis sp. nov. is typically insect $A+T$ biased, (75.1\%). Either strong A skew (AT-skew=0.16) or C skew (GC-skew=-0.17) are not shown in the whole mitogenome. However, the slightly A skew (rrnL: 0.14; rrnS: 0.17 ) and strongly $C$ skew ( $r r n L:-0.26$; $r r n S:-0.28$ ) are detected in $r r n L$ and rrnS genes. In addition, there are strong $A$ skew (AT-skew=0.11) and slight $C$ skew (GC-skew=-0.05) in the A+T-rich region. The comparison of nucleotide compositional 
skew of the whole mitogenomes, $r r n L$ genes, $r r n S$ genes and the A+T-rich regions of Oedipodinae grasshoppers are represented in Table 4.

TABLE 4. General nucleotide composition of complete mitogenome and nucleotide compositional skew of the Oedipodinae mitogenomes, $r r n L$ genes, $r r n S$ genes and the A+Trich regions in Oedipodinae grasshoppers. A (\%), C (\%), G (\%) and T (\%) mean the percentage of adenine, thymine, guanine and cytosine. The number with asterisk $\left({ }^{*}\right)$ means the average nucleotide compositional skew in the subfamily Oedipodinae.

\begin{tabular}{|c|c|c|c|c|c|c|c|c|}
\hline \multirow[b]{2}{*}{ Species } & \multirow[b]{2}{*}{$\begin{array}{c}\text { Accession } \\
\text { No. }\end{array}$} & \multirow[b]{2}{*}{$\begin{array}{l}\text { Length } \\
\text { (bp) }\end{array}$} & \multicolumn{6}{|c|}{ whole mitogenome } \\
\hline & & & $A(\%)$ & $\mathrm{T}(\%)$ & $\mathrm{G}(\%)$ & $\mathrm{C}(\%)$ & $\begin{array}{c}\text { AT- } \\
\text { skew }\end{array}$ & $\begin{array}{l}\text { GC- } \\
\text { skew }\end{array}$ \\
\hline Aiolopus thalassinus & NC_034674 & 15,753 & 44.4 & 30.9 & 10.4 & 14.3 & 0.18 & -0.16 \\
\hline Angaracris barabensis & NC_025558 & 15,930 & 43.6 & 31.7 & 10.1 & 14.4 & 0.16 & -0.18 \\
\hline Angaracris rhodopa & NC_025946 & 15,930 & 43.8 & 31.6 & 10.2 & 14.4 & 0.16 & -0.17 \\
\hline Bryodema luctuosum luctuosum & HQ833839 & 15,946 & 43.6 & 31.3 & 10.3 & 14.8 & 0.16 & -0.18 \\
\hline Bryodema miramae miramae & KP889242 & 15,919 & 43.8 & 31.7 & 10.1 & 14.4 & 0.16 & -0.18 \\
\hline Compsorhipis davidiana & NC_029408 & 16,085 & 43.9 & 31.5 & 10.0 & 14.6 & 0.16 & -0.19 \\
\hline Gastrimargus marmoratus & NC_011114 & 15,924 & 45.6 & 29.6 & 9.6 & 15.2 & 0.21 & -0.23 \\
\hline Hilethera xinjiangensis sp. nov. & in this study & 16,145 & 43.5 & 31.6 & 10.3 & 14.6 & 0.16 & -0.17 \\
\hline Locusta migratoria & NC_001712 & 15,722 & 44.5 & 30.8 & 10.1 & 14.6 & 0.18 & -0.18 \\
\hline Locusta migratoria manilensis & NC_014891 & 15,895 & 44.7 & 30.7 & 10.0 & 14.6 & 0.19 & -0.19 \\
\hline Locusta migratoria migratoria & NC_011119 & 16,053 & 44.8 & 30.7 & 9.9 & 14.6 & 0.19 & -0.19 \\
\hline Locusta migratoria tibetensis & NC_015624 & 15,568 & 44.3 & 31.0 & 10.2 & 14.5 & 0.18 & -0.17 \\
\hline Oedaleus infernalis & NC_029327 & 16,259 & 45.0 & 30.4 & 10.0 & 14.6 & 0.19 & -0.19 \\
\hline Oedaleus decorus asiaticus & NC_011115 & 15,898 & 45.5 & 30.6 & 9.8 & 14.2 & 0.20 & -0.18 \\
\hline Pternoscirta caliginosa & NC_035227 & 15,598 & 44.6 & 30.7 & 10.1 & 14.6 & 0.18 & -0.18 \\
\hline Trilophidia annulata & NC_ 027179 & 15,775 & 43.2 & 31.7 & 10.6 & 14.5 & 0.15 & -0.16 \\
\hline
\end{tabular}
continued.

\begin{tabular}{|c|c|c|c|c|c|c|}
\hline \multirow[b]{2}{*}{ Species } & \multicolumn{2}{|c|}{$r r n L$ genes } & \multicolumn{2}{|c|}{$r r n S$ genes } & \multicolumn{2}{|c|}{$A+T$-rich region } \\
\hline & AT-skew & GC-skew & AT-skew & GC-skew & AT-skew & GC-skew \\
\hline Aiolopus thalassinus & 0.18 & -0.24 & 0.21 & -0.27 & 0.13 & -0.13 \\
\hline Angaracris barabensis & 0.16 & -0.27 & 0.19 & -0.21 & 0.04 & -0.08 \\
\hline Angaracris rhodopa & 0.16 & -0.27 & 0.18 & -0.20 & 0.05 & -0.09 \\
\hline Bryodema luctuosum luctuosum & 0.15 & -0.24 & 0.19 & -0.23 & 0.05 & -0.12 \\
\hline Bryodema miramae miramae & 0.16 & -0.27 & 0.19 & -0.21 & 0.05 & -0.11 \\
\hline Compsorhipis davidiana & 0.16 & -0.28 & 0.18 & -0.20 & 0.08 & -0.21 \\
\hline Gastrimargus marmoratus & 0.17 & -0.28 & 0.21 & -0.28 & 0.23 & -0.32 \\
\hline Hilethera xinjiangensis sp. nov. & 0.14 & -0.26 & 0.17 & -0.28 & 0.11 & -0.05 \\
\hline Locusta migratoria & 0.14 & -0.24 & 0.20 & -0.24 & 0.17 & -0.27 \\
\hline Locusta migratoria manilensis & 0.16 & -0.25 & 0.19 & -0.22 & 0.21 & -0.36 \\
\hline Locusta migratoria migratoria & 0.16 & -0.25 & 0.20 & -0.24 & 0.23 & -0.46 \\
\hline Locusta migratoria tibetensis & 0.16 & -0.25 & 0.21 & -0.22 & 0.06 & -0.05 \\
\hline Oedaleus infernalis & 0.18 & -0.29 & 0.22 & -0.22 & 0.16 & -0.14 \\
\hline Oedaleus decorus asiaticus & 0.19 & -0.31 & 0.20 & -0.20 & 0.19 & -0.23 \\
\hline Pternoscirta caliginosa & 0.17 & -0.27 & 0.21 & -0.26 & 0.10 & -0.24 \\
\hline Trilophidia annulata & 0.15 & -0.26 & 0.19 & -0.25 & 0.10 & -0.13 \\
\hline
\end{tabular}


The conventional start/stop codons and incomplete stop codons are represented in the PCGs (see details in Table 3). All the protein-coding genes (PCGs) in the mitogenome start with a typical ATN codon but end with different stop codons. The complete stop codon TAA are found in genes atp8, atp6, $\operatorname{cox} 1, \operatorname{cox} 3$, cytb, nd4, nd4l,nd6, and TAG are in genes $n d 1$ and $n d 3$, respectively. Whereas, the incomplete stop codons $(\mathrm{T})$ are found in cox2, $n d 2$ and $n d 5$. The total number of codons in PCGs is 3,717 , and the most common amino acids in mitochondrial proteins are leucine (Leu, 504), isoleucine (lle, 391), and phenylalanine (Phe, 351) (Table 5).

TABLE 5. Codon number and RSCU in Hilethera xinjiangensis sp. nov. mitochondrial PCGs. A total of 3,717 codons were analyzed, excluding the initiation and termination codons. Amino acids encoded by these codons are labelled according to the IUPAC-IUB single-letter amino acid codes.

\begin{tabular}{cccccccccccc}
\hline Codon & Count & RSCU & Codon & Count & RSCU & Codon & Count & RSCU & Codon & Count & RSCU \\
\hline UUU(F) & 286 & 1.63 & UCU(S) & 108 & 2.39 & UAU(Y) & 149 & 1.75 & UGU(C) & 43 & 1.83 \\
UUC(F) & 65 & 0.37 & UCC(S) & 19 & 0.42 & UAC(Y) & 21 & 0.25 & UGC(C) & 4 & 0.17 \\
UUA(L2) & 312 & 3.71 & UCA(S) & 115 & 2.55 & UAA $\left({ }^{*}\right)$ & 0 & 0 & UGA(W) & 91 & 1.82 \\
UUG(L2) & 46 & 0.55 & UCG(S) & 3 & 0.07 & UAG (*) & 0 & 0 & UGG(W) & 9 & 0.18 \\
CUU(L1) & 59 & 0.7 & CCU(P) & 59 & 1.74 & CAU(H) & 54 & 1.5 & CGU(R) & 19 & 1.41 \\
CUC(L1) & 2 & 0.02 & CCC(P) & 6 & 0.18 & CAC(H) & 18 & 0.5 & CGC(R) & 1 & 0.07 \\
CUA(L1) & 76 & 0.9 & CCA(P) & 66 & 1.94 & CAA(Q) & 58 & 1.87 & CGA(R) & 32 & 2.37 \\
CUG(L1) & 9 & 0.11 & CCG(P) & 5 & 0.15 & CAG(Q) & 4 & 0.13 & CGG(R) & 2 & 0.15 \\
AUU(I) & 333 & 1.7 & ACU(T) & 49 & 0.97 & AAU(N) & 151 & 1.68 & AGU(S) & 26 & 0.58 \\
AUC(I) & 58 & 0.3 & ACC(T) & 19 & 0.37 & AAC(N) & 29 & 0.32 & AGC(S) & 3 & 0.07 \\
AUA(M) & 249 & 1.7 & ACA(T) & 131 & 2.58 & AAA(K) & 73 & 1.51 & AGA(S) & 81 & 1.8 \\
AUG(M) & 44 & 0.3 & ACG(T) & 4 & 0.08 & AAG(K) & 24 & 0.49 & AGG(S) & 6 & 0.13 \\
GUU(V) & 94 & 2.09 & GCU(A) & 67 & 1.77 & GAU(D) & 62 & 1.68 & GGU(G) & 91 & 1.7 \\
GUC(V) & 9 & 0.2 & GCC(A) & 8 & 0.21 & GAC(D) & 12 & 0.32 & GGC(G) & 5 & 0.09 \\
GUA(V) & 73 & 1.62 & GCA(A) & 75 & 1.99 & GAA(E) & 64 & 1.66 & GGA(G) & 101 & 1.89 \\
GUG(V) & 4 & 0.09 & GCG(A) & 1 & 0.03 & GAG(E) & 13 & 0.34 & GGG(G) & 17 & 0.32 \\
\hline
\end{tabular}

The lengths of the 22 rRNA genes range from 63 to $71 \mathrm{bp}$. Two rRNA genes ( $r r n L$ and $r r n S$ ), separated by tRNA-Val, are located between tRNA-Leu ${ }^{1}$ and A+Trich region. The lengths of $r r n L$ and $r r n S$ are 1,287 and $782 \mathrm{bp}$, respectively. Their $\mathrm{A}+\mathrm{T}$ contents are $76.9 \%$ and $74.5 \%$, respectively. The A+T-rich region of $1,332 \mathrm{bp}$, with an $A+T$ content of $83.2 \%$, is located between $r r n S$ and tRNA-Ile. 
Mitogenomic comparisons within Oedipodinae. The nucleotide base composition comparison for 16 Oedipodinae species were represented in Table 4. The highest and lowest $\mathrm{A}+\mathrm{T}$ content of the whole mitogenome are Oedaleus decorus asiaticus (76.1\%) and Bryodema luctuosum luctuosum (74.9\%), respectively; and $H$. xinjiangensis ranked in the third place. The nucleotide compositional skew of the whole mitogenomes, $r r n L$ genes, $r r n S$ genes and the $A+T$-rich regions of Oedipodinae species are also represented (Table 4, Fig. 4).

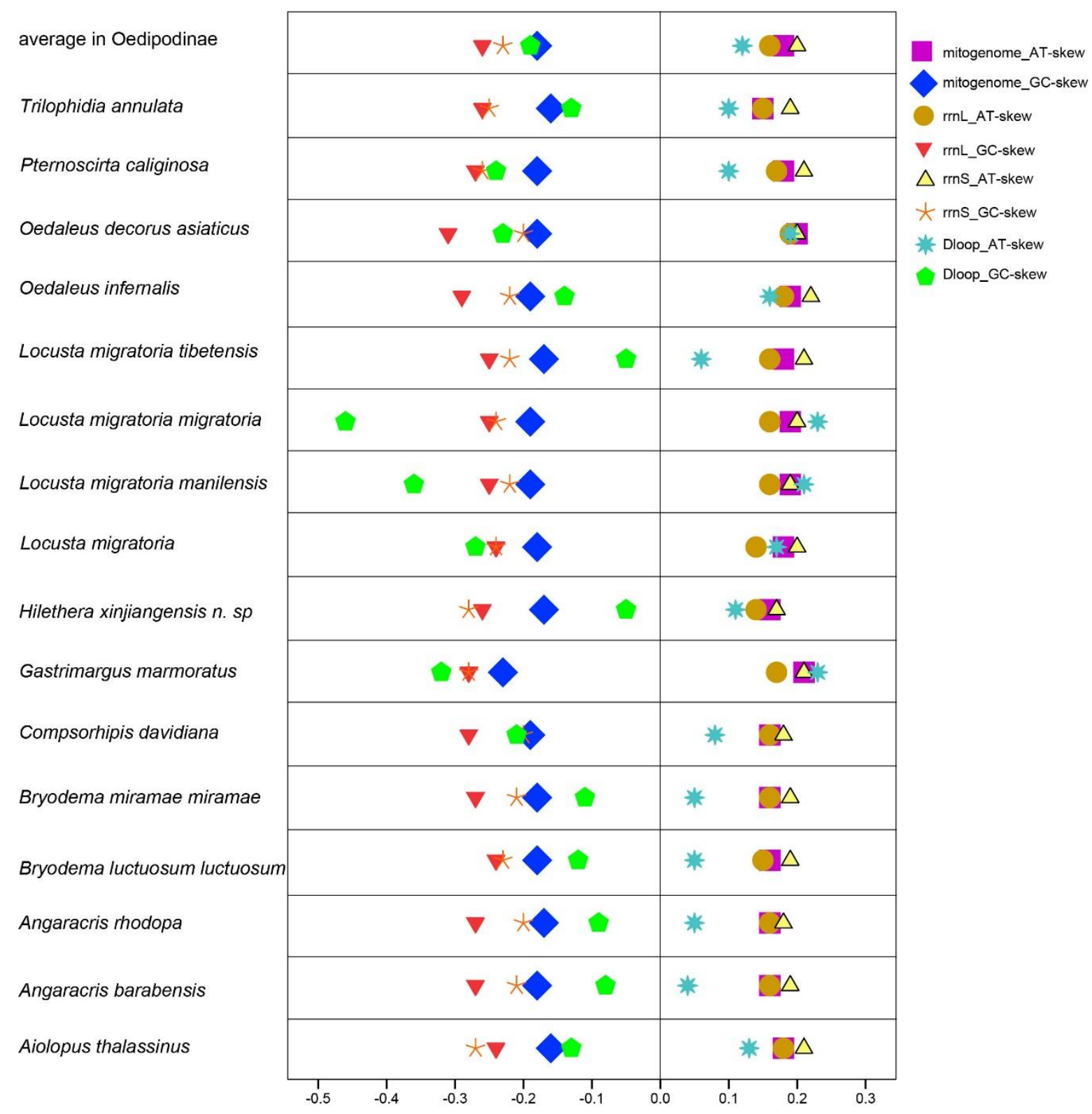

FIGURE 4. Comparison of AT-skew and GC-skews of Oedipodinae species. 
The pairwise genetic distance within 16 species based on single PCG, rrnL and $r r n S$ are shown in Fig. 5. The gene $r r n L$ is the least conserved gene (median $0.850,25-75$ percentile range $0.840-0.910$ ) and cox 1 is the most conserved gene (median $0.87,25-75$ percentile range $0.855-0.885$ ).

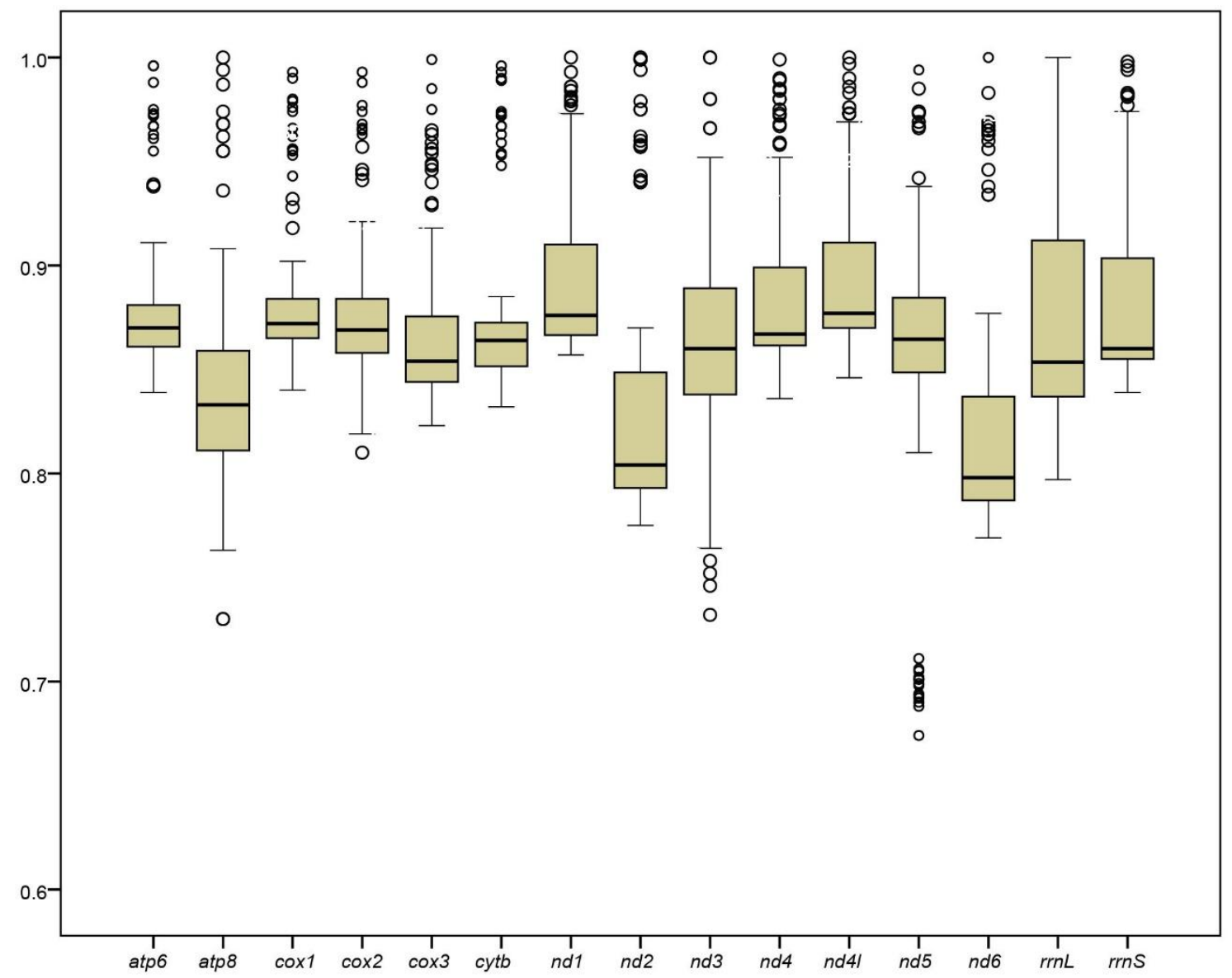

FIGURE 5. Genetic distance of individual genes within Oedipodinae. Each boxplot represents $\mathrm{P}$ distance for 13 PCGs, rrnL and $r r n S$ in sixteen Oedipodinae species. Lower horizontal bar, non-outlier smallest observation; lower edge of rectangle, 25 percentile; central bar within rectangle, median; upper edge of rectangle, 75 percentile; upper horizontal non-outlier largest observation; open circle, outlier.

The evolution rate of $\mathrm{Ka} / \mathrm{Ks}$ for all PCGs within Oedipodinae were shown in Fig. 6. The overall $\mathrm{Ka} / \mathrm{Ks}$ values are less than 1.0 within Oedipodinae, indicating the existence of purifying selection in these species. The evolutionary rate of cytochrome c oxidase complex genes ( $\operatorname{cox} 1, \operatorname{cox} 2, \operatorname{cox} 3)$ is overall lower than that of $\mathrm{NADH}$ dehydrogenase complex genes ( $n d 1-n d 6)$. Thereinto, the highest rate is $n d 5$ and the lowest is cox1. In addition, the evolutionary rate of gene cytb is located in the second lowest place, whereas, the gene atp8 was in the second highest place following $n d 5$. 


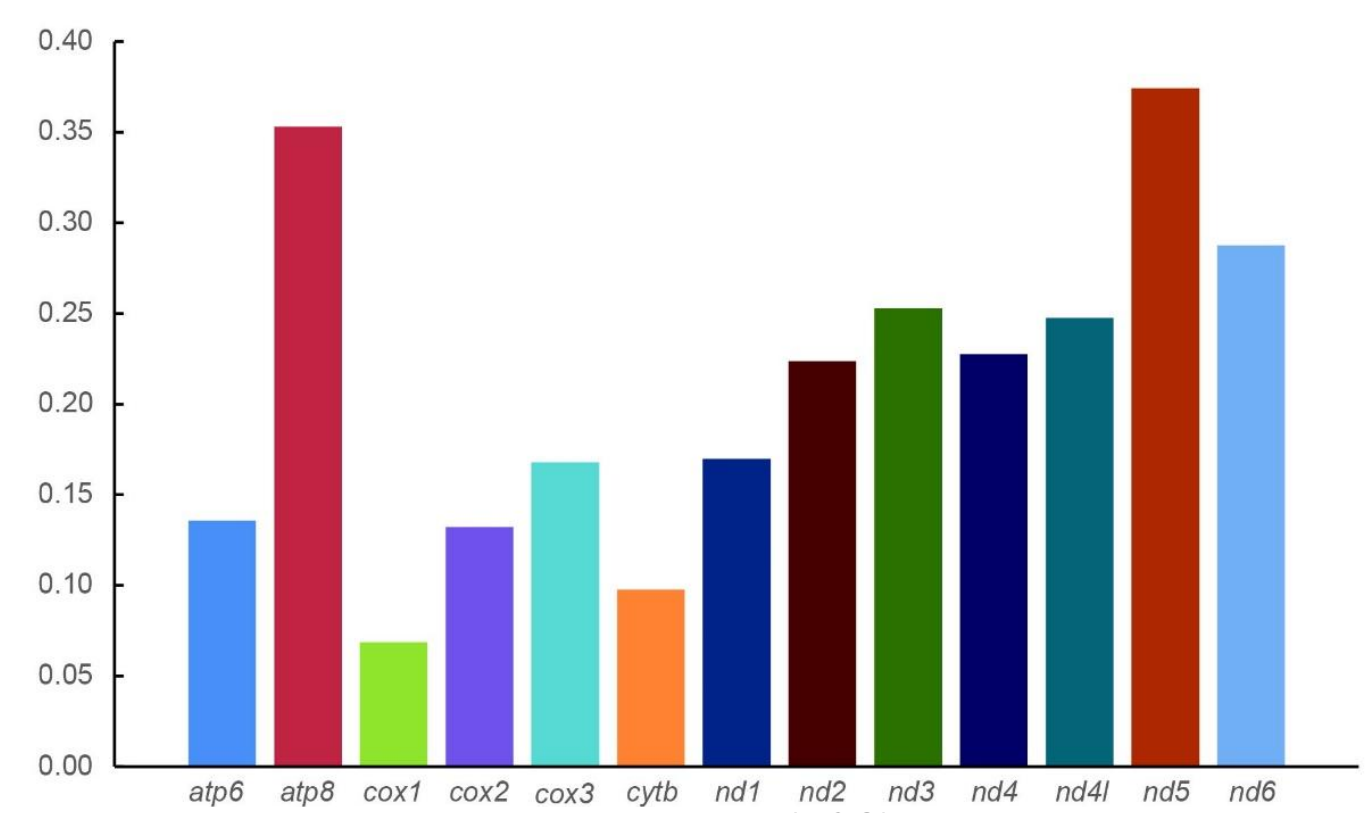

FIGURE 6. Evolution rates of each protein-coding (PCG) in the oedipodine mitogenomes.

Phylogenetic analyses. The best-fit partition schemes and substitution models used in $\mathrm{BI}$ and $\mathrm{ML}$ analyses of the combine dataset are shown in Table 6. Both $\mathrm{BI}$ and $\mathrm{ML}$ phylogenetic analyses yielded robust and largely congruent topologies (Fig. 7; see also supporting information Fig. S1 for original outputs of both $\mathrm{BI}$ and $\mathrm{ML}$ analyses). Both $\mathrm{BI}$ and $\mathrm{ML}$ analyses inferred that subfamilies Acridinae, Gomphocerinae and Oedipodinae are not monophyletic, in accordance with the previous studies (Chapco \& Contreras, 2011; Song et al., 2018). In BI analyses, except for Orinhipps tibetanus, the remaining species in the subfamily Gomphocerinae form one separated clade with well supported ( $P P=1.0)$, whereas the $\mathrm{ML}$ result inferred that they were divided into two different clades (Fig 7; see ML original output in Figure S1). Except for one species of Gomphocerinae (Orinhipps tibetanus), the subfamily Oedipodinae formed one clade and is sister to Acridinae.

Within Oedipodinae subfamily, all species belonging to the same genus form clades, except for Bryodema genus (Fig. 7). The subfamily Oedipodinae includes three main clades with high support (1.0 for PP and $100 \%$ for BV). The genera Trilophidia and Aiolopus form a clade independently. Remaining genera and species are formed the third clade with two main clades (hereby referred as clade $A$ and $B$ in Fig. 7). Within the clade $A$, two Bryodema species are nested in the clade of (Compsorhipis + Angaracris), then forming a sister group to the genus Hilethera. Within the clade B, the genus Pternoscirta is the first lineage to branch off, sister to 
the remaining three genera. The phylogenetic relationship among these three genera is not congruent in $\mathrm{BI}$ and $\mathrm{ML}$ analyses. In $\mathrm{BI}$ analyses, the genus Gastrimargus grouped together with the genus Locusta ( 0.81 for PP), sister to the genus Oedaleus (1.0 for PP). Whereas the position of two genera Locusta and Oedaleus was swapped in ML analyses with high support (84\% for BV).

TABLE 6. Best-fit models of sequence evolution and partitioning schemes selected with PartitionFinder for phylogenetic reconstructions using Bayesian Inference (MrBayes) and Maximun Likelihood (IQ-TREE). Codon position is denoted by pos1, pos2 and pos3. Subsets are denoted by $\mathrm{p} 1, \mathrm{p} 2$ and $\mathrm{p} 3$.

\begin{tabular}{|c|c|c|}
\hline Analyses & Partitions & Models \\
\hline \multirow[t]{3}{*}{ Bayesian inference $(\mathrm{BI})$ analyses } & $\begin{array}{l}\text { p1: atp6_pos1, atp6_pos2, atp6_pos3, atp8_pos1, } \\
\text { atp8_pos2, atp8_pos3, cox1_pos1, cox1_pos2, cox1_pos3, } \\
\text { cox2_pos1, cox2_pos2, cox2_pos3, cox3_pos1, cox3_pos2, } \\
\text { cox3_pos3, cytb_pos1, cytb_pos2, cytb_pos3, nd1_pos1, } \\
\text { nd1_pos2, nd2_pos1, nd2_pos2, nd2_pos3, nd3_pos1, } \\
\text { nd3_pos2, nd3_pos3, nd4_pos1, nd4_pos2, nd41_pos1, } \\
\text { nd41_pos2, nd6_pos1, nd6_pos2, nd6_pos3, rrnL }\end{array}$ & $\mathrm{GTR}+\mathrm{l}+\mathrm{G}$ \\
\hline & p2: nd5_pos3, nd1_pos3, nd4_pos3, nd4l_pos3 & $\mathrm{HKY}+\mathrm{G}$ \\
\hline & p3: nd5_pos2, nd5_pos1, rrnS & $\mathrm{GTR}+\mathrm{G}$ \\
\hline \multirow[t]{2}{*}{$\begin{array}{l}\text { Maximum likelihood (ML) } \\
\text { analyses }\end{array}$} & $\begin{array}{l}\text { p1: atp6_pos1, atp6_pos2, atp8_pos1, atp8_pos2, } \\
\text { cox1_pos1, cox1_pos2, cox2_pos1, cox2_pos2, cox3_pos1, } \\
\text { cox3_pos2, cytb_pos1, cytb_pos2, nd1_pos1, nd1_pos2, } \\
\text { nd2_pos1, nd2_pos2, nd2_pos3, nd3_pos1, nd3_pos2, } \\
\text { nd4_pos1, nd4_pos2, nd4I_pos1, nd41_pos2, nd6_pos1, } \\
\text { nd6_pos3, rrnL }\end{array}$ & $\mathrm{GTR}+\mathrm{l}+\mathrm{G}$ \\
\hline & $\begin{array}{l}\text { p2: atp6_pos3, atp8_pos3, cox1_pos3, cox2_pos3, } \\
\text { cox3_pos3, cytb_pos3, nd1_pos3, nd3_pos3, nd4_pos3, } \\
\text { nd41_pos3, nd5_pos1, nd5_pos2, nd5_pos3, nd6_pos2, rrns }\end{array}$ & $\mathrm{GTR}+\mathrm{G}$ \\
\hline
\end{tabular}

\section{Discussion}

The new species $H$. xinjiangensis sp. nov. was described, which supplements the basic data for the genus and expands its distribution to the northern part of China. The new species resembles the species $H$. turanica from Xinjiang and $H$. brevipennis from Shanxi province, from which the new species differs by general coloration darker, shorter tegmina, two faint coloration-banded strip in forewings and hind tibiae, and broader cubital area in forewings.

The first mitogenome of the genus Hilethera grasshopper was sequenced, which allows comparison with existing mitogenomes from the diverse subfamily Oedipodinae. The gene order and orientation within the mitogenome of $H$. xinjiangensis sp. nov. are identical with those described for other oedipodine species. The length of the whole mitogenome and the length range for tRNAs in $H$. xinjiangensis sp. nov. are also very close to Oedipodinae. The genes $r r n L$ of these 
16 Oedipodinae species are weakly AT-skewed (0.14 to 0.19) and strongly GCskewed (-0.24 to -0.29$)$. However, the nucleotide compositional skew between the whole mitogenome, rrnS and $\mathrm{A}+\mathrm{T}$-rich region differ amongst species. It is logical that the nucleotide compositional skew in different genes slightly different, but more mitogenomes of other Oedipodine species are necessary to test whether this tendency is consistent between species.

The pairwise genetic distance shows that cox1 is the most conserved gene in the mitogenomes of oedpodines, confirming it as a useful marker to infer phylogenetic relationships at higher taxonomic levels. Meanwhile, the gene rrnL could be a useful marker for barcoding approaches or for inferring phylogenetic relationships between closely related species since it is the most variable gene among the species of oedipodines. According to the $\mathrm{Ka} / \mathrm{Ks}$ ratio, the evolutionary rate of the Cytochrome Oxidase complex ( $\operatorname{cox} 1, \operatorname{cox} 2$ and $\operatorname{cox} 3)$ and cytb genes are lower than that of in NADH dehydrogenase complex. In addition, the disparity of the divergence evolutionary rates in the latter is not significant, expect for the gene nd5. However, there is an obvious evolutionary rate discrepancy in ATP synthase. The evolutionary rate of the gene atp8 is far higher than that of apt6, ranking at the secondary place after nd5. In view of lowest conserved gene $r r n L$ and the highest evolutionary rate of the gene $n d 5$, the present study revealed these two genes as potential markers for future phylogenetic study between the closely related species within Oedipodinae. Our results confirm that the mitogenomes in grasshoppers have a relatively stable structural and functional evolution, as suggested by studies in Orthoptera (Song et al., 2015; Dong et. al., 2017) and in insects in general (e.g. Simon et al., 2006; Cameron, 2014; Konstantinov et al., 2016).

The phylogenetic relationship among the subfamilies Acridinae, Gomphocerinae and Oedipodinae using mitogenomes inferred in this study, are mostly congruent with the previous studies dealing with the phylogeny of Acrididae (Chapco \& Contreras, 2011; Song et al., 2018). The previous studies inferred that the three subfamilies were not monophyletic. However,our BI analyses showed that except for one species (Orinhippus tibetanus), all gomphocerine species form one clade. Similarly, within Oedipodinae, the positions of the genera Bryodema and Gastrimargus are incongruent in $\mathrm{Bl}$ and $\mathrm{ML}$ analyses, respectively. More complete mitogenome or genomic data are needed to reconstruct phylogenetic relationship within Oedipodinae, and for the further study within Acrididae. 


\section{Acknowledgements}

This work was conducted in the context of the PhD thesis of JD, which was funded by China Scholarship Council (CSC), the Innovation Funds of Graduate Programs of Shaanxi Normal University [2012CXB019], the National Natural Science Foundation of China [Grant No. 31402006, Grant No. 31872273]. We thank Libin Ma (Shaanxi Normal University, China) for taking photographers. We appreciate, Jose Luis Benavides Lopez, Bruno Dastillung and Maram Caesar (Muséum national d'Histoire naturell, France) for offering relevant documents.

\section{References}

Bey-Bienko, G.Y. \& Mistshenko, L.L. (1951) Locusts and Grasshoppers of the U.S.S.R. and Adjacent Countries 2, 570.

Bernt, M., Donath, A., Juhling, F., Externbrink, F., Florentz, C., Fritzsch, G., Putz, J., Middendorf, M. \& Stadler, P.F. (2013) MITOS: Improved de novo metazoan mitochondrial genome annotation. Molecular Phylogenetics and Evolution, 69, 313-319. https://doi.org/10.1016/j.ympev.2012.08.023

Bolger, A.M., Lohse, M. \& Usadel, B. (2014) Trimmomatic: a flexible trimmer for Illumina sequence data. Bioinformatics, 30 (15), 2114-2120.

Bolivar, I. (1902) Les Orthoptères de St-Joseph's College à Trichinopoly (Sud de I'Inde). Annales de la Société entomologique de France, 602-603.

Bughio, B.A., Sultana, R. \& Wagan, M.S. (2012) A new species of the genus Hilethera Uvarov (Oedipodinae: Acrididae: Orthoptera) from Pakistan. Journal of Cell and Animal Biology, 6(2), 29-30.

Cameron, S.L. (2014) Insect Mitochondrial Genomics: Implications for Evolution and Phylogeny. Annual Review of Entomology, 59, 95-117.

https://doi.org/10.1146/annurev-ento-011613-162007

Chapco, W. \& Contreras, D. (2011) Subfamilies Acridinae, Gomphocerinae and Oedipodinae are "fuzzy sets": a proposal for a common African origin. Journal of Orthoptera Research, 20, 2173-2190.

Cigliano, M.M., H. Braun, D.C. Eades \& Otte, D. (2018) Orthoptera Species File. Version 5.0/5.0. [April 2018] <http://Orthoptera.SpeciesFile.org>.

Crampton-Platt, A., Yu, D.W., Zhou, X. \& Vogler, A.P. (2016) Mitochondrial metagenomics: letting the genes out of the bottle. GigaScience, $5,12$.

https://doi.org/10.1186/s13742-016-0120-y 
Dirsh, V.M. (1958) Acridological notes. Tijdschrift voor Entomologie (Tijdschr. v. Entomologie), 101, 56.

Dirsh, V.M. (1965) African genera of Acridoidea. The Anti-locust Research Centre at the University Press, Cambridge.

Dong, J., Vicente, N., Chintauan-Marquier, I.C., Ramadi, C., Dettai, A. \& Robillard, T. (2017) Complete mitochondrial genome and taxonomic revision of Cardiodactylus muiri Otte, 2007 (Gryllidae: Eneopterinae: Lebinthini). Zootaxa, 4268, 101-116.

Fries, M., Chapco, W. \& Contreras, D. (2007) A molecular phylogenetic analysis of the Oedipodinae and their intercontinental relationships. Journal of Orthoptera Research, 16 (2): 115-125.

Hahn, C., Bachmann, L. \& Chevreux, B. (2013) Reconstructing mitochondrial genomes directly from genomic next-generation sequencing reads-a baiting and iterative mapping approach. Nucleic Acids Research, 41(13), e129.

Hajibabaei, M., Singer, G.A.C., Hebert, P.D.N. \& Hickey, D.A. (2007) DNA barcoding: how it complements taxonomy, molecular phylogenetics and population genetics. Trends in genetics, 23(4), 167-172.

Husemann, M., Namkung, S., Habel, J. C., Danley, P. D., \& Hochkirch, A. (2012) Phylogenetic analyses of band-winged grasshoppers (Orthoptera, Acrididae, Oedipodinae) reveal convergence of wing morphology. Zoologica Scripta, 41(5), 515526.

doi:10.1111/j.1463-6409.2012.00548.x

Konstantinov, Y.M., Dietrich, A., Weber-Lotfi, F., Ibrahim, N., Klimenko, E.S., Tarasenko, V.I., Bolt, T.A. \& Koulintchenko, M.V. (2016) DNA import into mitochondria. Biochemistry (Moscow), 81, 1044-1056.

https://doi.org/10.1134/S0006297916100035

Kumar, S., Stecher, G. \& Tamura, K. (2016) MEGA7: Molecular Evolutionary Genetics Analysis Version 7.0 for Bigger Datasets. Molecular Biology and Evolution, 33, 18701874.

https://doi.org/10.1093/molbev/msw054

Lanfear, R., Frandsen, P.B., Wright, A.M., Senfeld, T., Calcott, B. (2017) PartitionFinder 2: new methods for selecting partitioned models of evolution for molecular and morphological phylogenetic analyses. Molecular Biology and Evolution, 34, 772-773.

Lowe, T.M. \& Chan, P. (2016) tRNAscan-SE On-line: integrating search and context for analysis of transfer RNA genes. Nucleic Acids Research, 44, W54-W57.

doi: 10.1093/nar/gkw413 
Miller, M.A., Schwartz, T., Pickett, B.E., He, S., Klem, E.B., Scheuermann, R.H., Passarotti, M., Kaufman, S. \& O'Leary, M.A. (2015) A RESTful API for access to phylogenetic tools via the CIPRES Science Gateway. Evolutionary Bioinformatics, 11, 43-48.

Nguyen, L.T., Schmidt, H.A., von Haeseler, A. \& Minh, B.Q. (2015) IQTREE: A fast and effective stochastic algorithm for estimating maximum likelihood phylogenies. Molecular Biology and Evolution, 32, 268-274.

Ronquist, F., Teslenko, M., van der Mark, P., Ayres, D.L., Darling, A., Höhna, S., Larget, B., Liu, L., Suchard, M. A \& Huelsenbeck, J.P. (2012) MrBayes 3.2: efficient Bayesian phylogenetic inference and model choice across a large model space. Systematic Biology, 61, 539-542.

Simon, C., Buckley, T.R., Frati, F., Stewart, J.B. \& Beckenbach, A.T. (2006) Incorporating Molecular Evolution into Phylogenetic Analysis, and a New Compilation of Conserved Polymerase Chain Reaction Primers for Animal Mitochondrial DNA. Annual Review of Ecology, Evolution, and Systematics, 37, 545-579.

https://doi.org/10.1146/annurev.ecolsys.37.091305.110018

Song, H., Amédégnato, C., Cigliano, M.M., Desutter-Grandcolas, L., Heads, S.W., Huang, Y., Otte, D. \& Whiting, M.F. (2015) 300 million years of diversification: elucidating the patterns of orthopteran evolution based on comprehensive taxon and gene sampling. Cladistics, 31, 621-651.

Song, H., Mariño-Pérez, R., Woller, D.A. \& Cigliano, M.M. (2018) Evolution, diversification, and biogeography of grasshoppers (Orthoptera: Acrididae). Insect Systematics and Diversity, 2(4), 3, 1-25.

https://doi:10.1093/isd/ixy008

Uvarov, B.P. (1923) Some new or little known grasshoppers from Palestine. The Entomologist's Monthly Magazine (Ent. Monthly Mag.), 3(9), 81-86.

Uvarov, B.P. (1925) The genus Hilethera Uv. and its species (Orth: Acrid). Eos, 1: 33-42.

Uvarov, B.P. (1940) Twenty-eight new generic names in Orthoptera. Annals and Magazine of Natural History, London (Ann. Mag. nat. Hist.), vol.11, 5, 173-176.

Uvarov, B.P. (1966) Grasshoppers and Locusts, Vol. 1. Cambridge University Press, Cambridge.

Vickery, V.R. (1977) Taxon ranking in Grylloidea and Gryllotalpoidea. Lyman Entomol. Mus. Res. Lab. Mem. 4, 1-31.

Vickery, V.R. (1989) The biogeography of Canadian Grylloptera and Orthoptera. Canadian Entomologist, 121, 389-424.

Vickery, V.R. (1997) Classification of the Orthoptera (sensu stricto) or Caelifera. In: Gangwere, S.K., Muralirangan, M.C., Muralirangan, M. (Eds.), The Bionomics of Grasshoppers, Katydids and Their Kin. CAB International, Wallingford, pp. 5-40. 
Vickery, V.R. \& Kevan, D.K.M. (1983) A monograph of the orthopteroid insects of Canada and adjacent regions. Lyman Entomol. Mus. Res. Lab. Mem. 13, 711-728.

Yin, X.C., Shi, J.P. \& Yin, Z. (1996) A synonymic catalogue of grasshoppers and their allies of the world: Orthoptera: Caelifera. China Forestry Pub. House, Beijing.

Zheng, Z.M. (1993) Taxonomy of grasshoppers. Shaanxi Normal University Press, Xi'an.

Zheng, Z.M. \& Lu, R.S. (2002) Two new species of grasshoppers (Orthoptera Acridoidea) from Zhongtiaoshan, Shanxi Province. Entomotaxonomia, 24(1), 16-20.

Zheng, Z.M. \& Xia, K.L. (1998) Fauna Sinica Insecta (Vol. 10) Orthoptera Acridoidae Oedipodidae and Arcypteridae. Science Press, Beijing. 


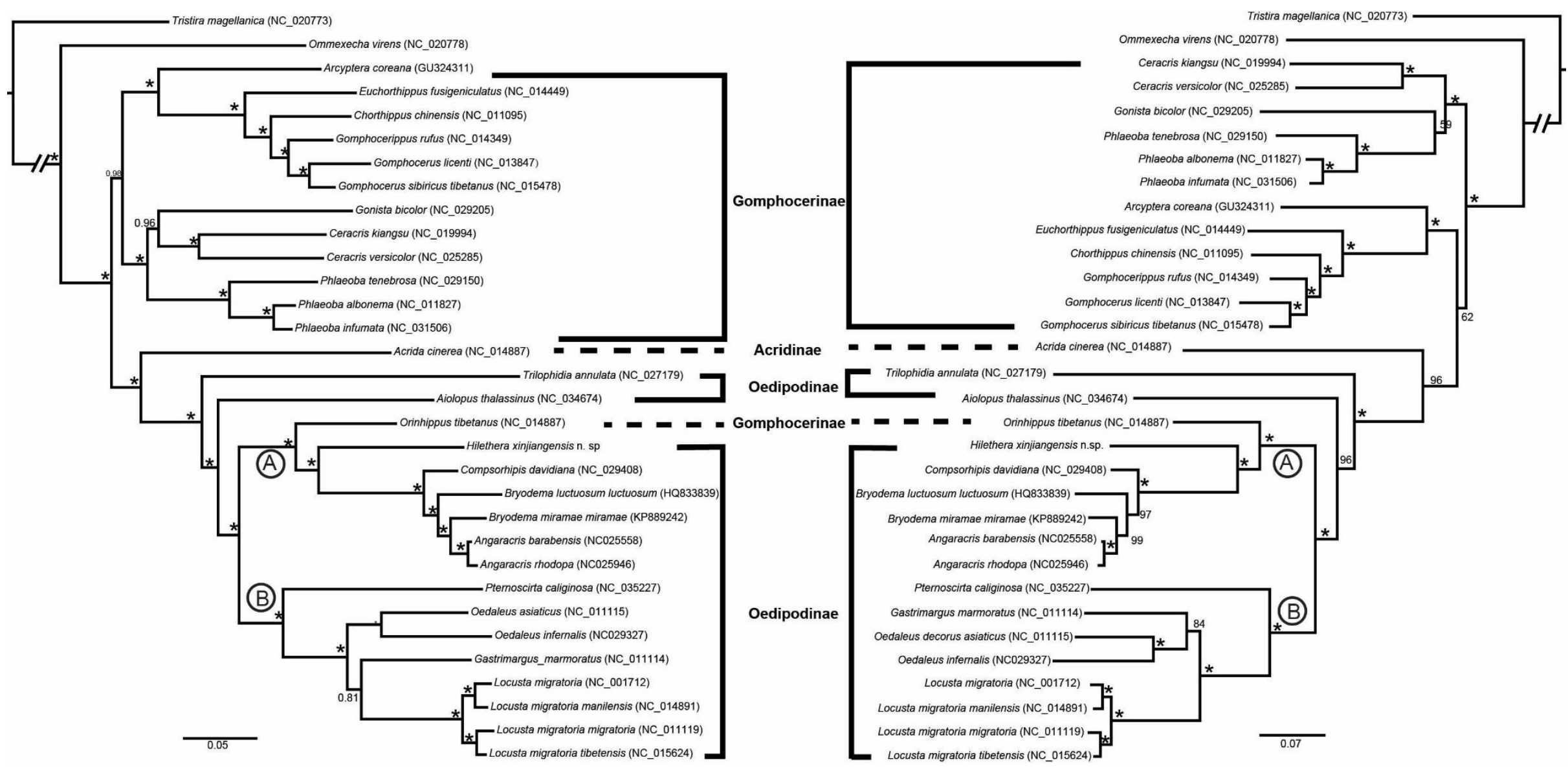

FIGURE 7. Phylogenetic reconstruction of Oedipodinae using mitochondrial PCGs and rRNAs concatenated dataset inferred from Bayesian inference ( $\mathrm{BI}$, on the left of figure) and Maximum likelihood (ML, on the right of figure). Values on nodes indicate branch support, $\mathrm{BI}$ posterior probabilities (PP) / Maximum likelihood Bootstrap support values (BV). Asterisks are used to indicate maximum support (1.0 for PP and 100\% for BV). Accession number of each species recorded in GenBank was indicated in the parentheses. 


\section{Supporting Information}

Figure $\mathrm{S}$ 1. The original output results from $\mathrm{BI}(\mathrm{A})$ and $\mathrm{ML}(\mathrm{B})$ analysis.

\section{(A) BI analysis result}

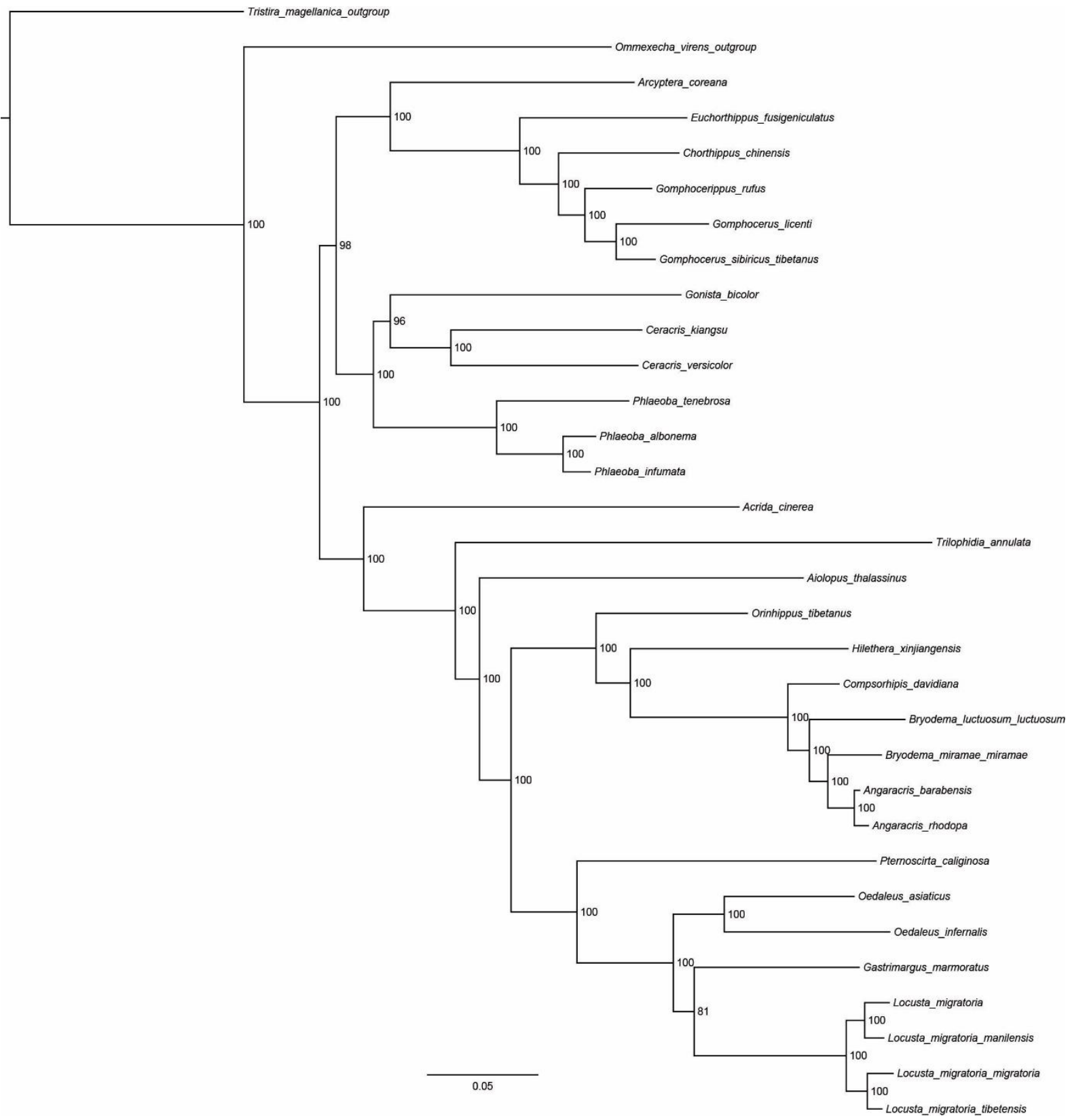


(B) ML analysis result

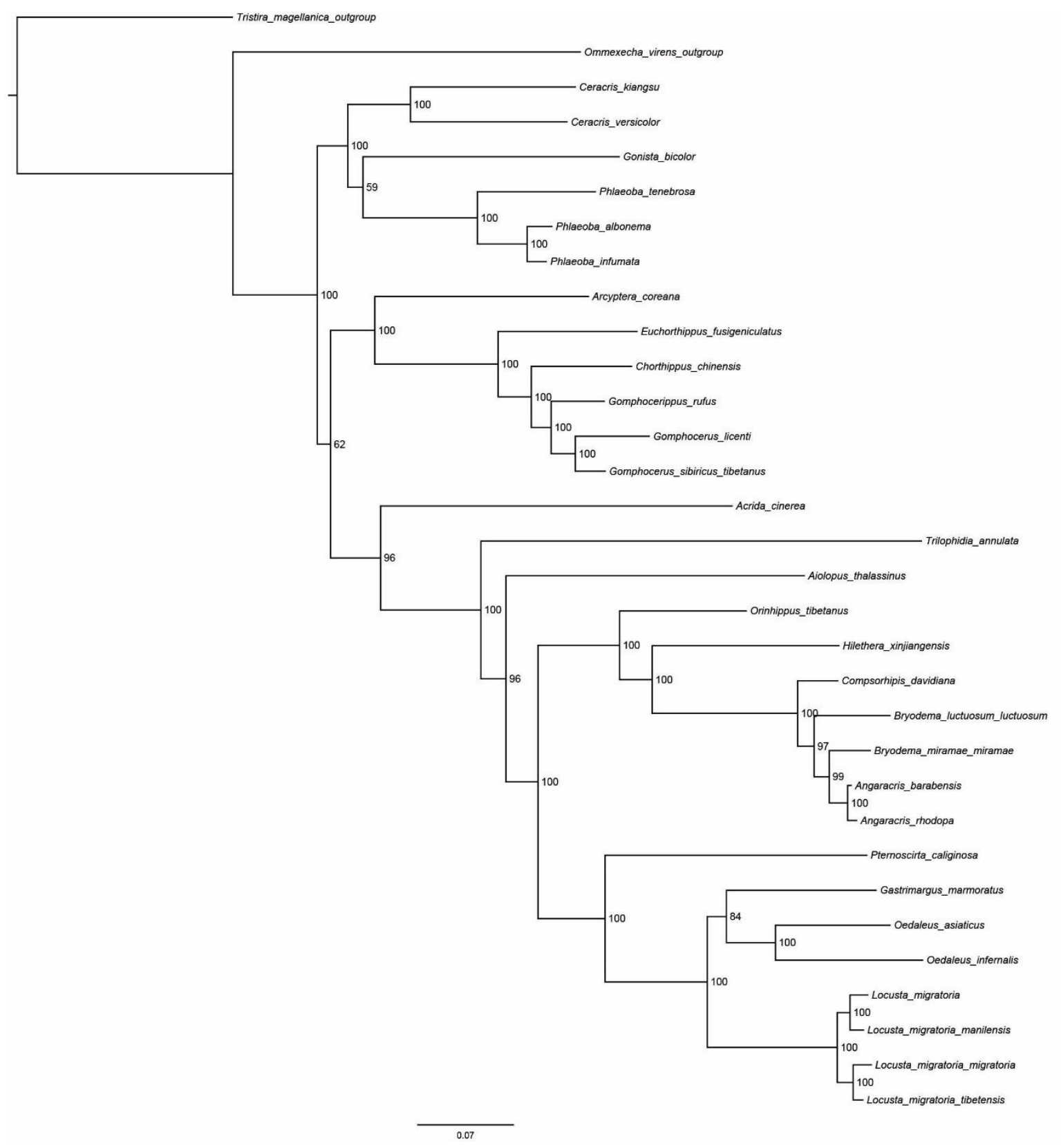

